\title{
A POEM BY JANKO MESSNER
}

\author{
Presented and translated by Tom Priestly \\ University of Alberta
}

Janko Messner, the doyen of intellectual life among the minority Slovenians in Koroška/Kärnten (Carinthia), Austria was born December 13, 1921 in the village of Dob/Aich; he studied Germanic, Romance and Slavic Literatures in Austria and Yugoslavia and 1963-1981 taught at the Slovene Gimnarija in Celovec/Klagenfurt. He did not begin writing until 1970 but his literary output since then was extensive: essays, short stories, filmscripts, dramas, poetry. Much was polemical, witty, satirical, but often tender and always passionate and engaged. Yugoslav Communists called him a lackey of the Austrian right wing, while Carinthian German nationalists castigated him for his left-wing views, especially after his championing of Nicaraguan revolutionaries and his collaboration with Ernesto Cardinal. In spite of his strongly-held views he was awarded many literary prizes in Austria and Slovenia. Personally, he was curmudgeonly and charming, usually the latter. After publishing some translations of his poetry in 1998, I visited him several times and worked on further translations with him; our interesting and annoying collaboration is described in "Multiple im/person/aliz/ations: Four Attempts to 'get under the skin' of Poets," TranscUlturAl Vol. 1, no. 4, 2011. Janko died on October 26, 2011. The following poem, first published in Pesmi in puščice, Ljubljana, 1991, shows that "he heard a different drummer" from his small-minded contemporaries and stepped to that rhythm. Most of the translation dates from our collaboration in his house in Osojnica/Zwanzgerberg in the late 1990s, with a few changes since his recent death.

\section{Dva tabora \\ Če se natanko pregleda stvari, v tabora dva se človeštvo deli: eni so v cunjah, a drugi v škrlatu, eni v palačah so, drugi pa v blatu. Eni umirajo lačni brez dela, druge pa stisne od mastnega jela. \\ Če se natanko pregleda stvari, v tabora dva se človeštvo deli: dvoje marksistov je zmeraj bilo, s knjižico eni, a drugi z vestjo. Enim je delo merilo človeka, drugi živijo od golega čveka.}

\section{Two camps}

If you look carefully, why, you will find there are two camps for all humankind: some dress in rags, the others in silk, some live in palaces, the others in filth. Some die of hunger, without any work; the others of heart disease: butter and pork.

If you look carefully, why, you will find there are two camps for all humankind: two kinds of Marxist right from the start, those from the book, and those from the heart. For some it is actions only that matter, For others it's words - meaningless chatter. 


\begin{tabular}{|l|l|}
\hline Če se natanko pregleda stvari, & If you look carefully, why, you will find \\
v tabora dva se človeštvo deli: & there are two camps for all humankind: \\
dvoje kristjanov ta božji svet tlači, & two kinds of Christian ruling the earth, \\
eni dejavni, a drugi žebrači. & some very active, the rest of no worth. \\
Eni brez greha bojé se pekla, & Those without sin live in dread fear of hell; \\
drugi pregrešno živé od Boga. & the others, self-righteously, sin very well. \\
& \\
\end{tabular}

